\title{
Pengaruh Model Pembelajaran Kolaboratif Berbantuan Peta Pikiran Terhadap Hasil Belajar IPA
}

\author{
Kadek Wiwin Mega Sari ${ }^{1 *}$, I Gede Margunayasa ${ }^{2}$, Ni Nyoman Kusmariyatni ${ }^{3}$ \\ 1,2,3 Jurusan Pendidikan Guru Sekolah Dasar, Fakultas Ilmu Pendidikan, Universitas Pendidikan Ganesha Singaraja, Indonesia
}

\section{ARTICLEIN \\ $\mathrm{FO}$ \\ Article history: \\ Received 21 May \\ 2018 \\ Received in revised \\ form \\ 22 June 2018 \\ Accepted 27 July \\ 2018 \\ Available online 26 \\ August 2018}

Kata Kunci:

hasil belajar,

kolaboratif, peta

pikiran .

Keywords:

collaborative, mind

map, science

learning result

\begin{abstract}
A B STRAK
Penelitian ini bertujuan mengetahui perbedaan yang signifikan hasil belajar IPA antara kelompok siswa yang dibelajarkan dengan model pembelajaran kolaboratif berbantuan peta pikiran dan kelompok siswa yang mengikuti pembelajaran konvensional. Jenis penelitian ini adalah kuasi eksperimen. Populasi dalam penelitian ini adalah seluruh siswa kelas V SD di Gugus VII Kecamatan Sawan dan sampel sebanyak 44 siswa ditentukan dengan teknik random sampling. Data hasil belajar IPA dikumpulkan dengan instrumen tes pilihan ganda. Teknik analisis yang digunakan adalah uji-t sampel independen. Hasil analisis menunjukkan bahwa terdapat perbedaan yang signifikan hasil belajar IPA antara kelompok siswa yang dibelajarkan dengan model pembelajaran kolaboratif berbantuan peta pikiran dan kelompok siswa yang mengikuti pembelajaran konvensional $\left(t_{\text {hitung }}=5,59>\right.$ $\left.t_{\text {tabel }}=2,021\right)$. Dari rata-rata hitung, diketahui bahwa rata-rata hasil belajar IPA kelompok eksperimen lebih besar dibandingkan rata-rata hasil belajar IPA kelompok kontrol $(22,81>17,00)$. Jadi model pembelajaran kolaboratif berbantuan peta pikiran berpengaruh terhadap hasil belajar IPA siswa kelas V SD di Gugus VII Kecamatan Sawan Tahun Pelajaran 2017/2018.
\end{abstract}

\section{A B S T R A C T}

This research aims to investigate the difference of science learning outcomes between students who followed collaborative learning model assited mind map and students who followed conventional learning. The type of this research was quasi experimental research with non-equivalent post-test only control group design. Population in this study was $5^{\text {th }}$ grade students of SD Gugus VII Sawan Subdistrict and the samples is 44 students were selected used random sampling technique. the science data were collected by using multiple choice test instruments. . The analysis technique used was t-test of independent sample. Result shows that there is a difference science learning outcomes between students who followed collaborative learning model assited mind map and students who followed conventional learning ( $t_{\text {hitung }}=6,06>t_{\text {tabel }}=2,021$ ). Moreover, it is known that the average science learning result experimental group is higher than average science learning result control group $(22,81$ $>17,17)$. This means that, the collaborative learning model assited mind map the science learning result of $5^{\text {th }}$ of elementary students in Cluster VII Sawan in the Academy Year 2017/2018.

\footnotetext{
* Corresponding author.

E-mail addresses: wiwinmegasari@gmail.com (Kadek Wiwin Mega Sari)
} 


\section{Pendahuluan}

IPA merupakan ilmu pengetahuan yang berkaitan dengan cara mencari tahu tentang alam secara sistematis, sehingga IPA bukan hanya penugasan kumpulan pengetahuan yang berupa fakta-fakta, konsepkonsep, atau prinsip-prinsip saja tetapi juga merupakan suatu proses penemuan (Permendiknas, 2006).

Menurut Nash (dalam Samatowa, 2010:3) menyatakan IPA adalah pengetahuan yang rasional dan objektif tentang alam semesta dengan segala isinya. IPA membahas tentang gejala-gejala alam yang disusun secara sistematis didasarkan pada hasil percobaan dan pengamatan yang dilakukan oleh manusia, sehingga IPA diajarkan di jenjang pendidikan sekolah dasar. Mata pelajaran IPA perlu diberikan kepada semua peserta didik mulai dari sekolah dasar untuk membekali peserta didik dengan kemampuan berpikir analitis, sistematis, kritis, dan kreatif, serta kemampuan bekerjasama. Kompetensi tersebut diperlukan agar peserta didik dapat memiliki kemampuan memperoleh, mengelola, dan memanfaatkan informasi untuk bertahan hidup pada keadaan yang selalu berubah, tidak pasti, dan kompetitif.

Tujuan mempelajari IPA di sekolah dasar adalah untuk membentuk siswa yang mampu menguasai konsep IPA dan keterkaitannya serta mampu mengembangkan sikap ilmiah untuk memecahkan masalahmasalah yang dihadapinya. Berdasarkan hal tersebut, perlu dirancang pembelajaran IPA yang mengarah kepencapaian kompetensi tersebut. Pembelajaran yang dirancang hendaknya menciptakan suasana lingkungan yang memungkinkan peserta didik melaksanakan kegiatan belajar IPA. Proses pembelajaran yang berpusat pada siswa, sehingga tujuan pembelajaran IPA dapat tercapai. Pembelajaran hendaknya memberikan kesempatan kepada siswa untuk mengoptimalkan dan memanfaatkan semua inderanya untuk belajar dengan mengaktifkan komunikasi, kerjasama, serta kolaborasi dengan siswa yang lain.

Upaya dalam merancang pembelajaran IPA, tidak lepas dari peran seorang guru. Sanjaya (dalam Susanto, 2013:32) mengemukakan bahwa guru adalah komponen yang sangat menentukan dalam implementasi suatu model pembelajaran. Seorang guru harus mampu menguasai konsep-konsep IPA dan menerapkan suatu model yang membuat siswa berperan aktif dalam mencari pengetahuannya sendiri. Pemilihan model pembelajaran yang tepat akan menciptakan suasana belajar yang menyenangkan, menarik, kondusif, dan interaktif dengan tetap memerhatikan tujuan dari pembelajaran tersebut.

Manfaat pembelajaran IPA dapat dirasakan oleh peserta didik ketika pembelajaran tersebut tidak monoton, mampu menarik perhatian, dan menyenangkan. Peserta didik akan menikmati pembelajaran yang dilaksanakan, sehingga terjadi peningkatan terhadap hasil belajar. Hasil belajar merupakan cerminan dari suatu pembelajaran. Susanto (2014:5) menyatakan bahwa "hasil belajar merupakan perubahan-perubahan yang terjadi pada diri siswa, baik yang menyangkut aspek kognitif, afektif, maupun psikomotor sebagai hasil dari kegiatan belajar". Solihati (2012) hasil belajar diperoleh dari interaksi siswa dengan lingkungan yang sengaja direncanakan guru dalam perbuatan mengajarnya. Berdasarkan pemaparan ahli, dapat disintesiskan bahwa hasil belajar merupakan hasil yang dicapai dalam proses pembelajaran dalam jangka waktu tertentu yang mencangkup sejumlah pengetahuan, keterampilan, dan prilaku dinyatakan dengan nilai atau angka dan adanya perubahan tingkah laku yang meliputi aspek kognitif, afektif dan psikomotor.

Faktanya pembelajaran IPA tidak seperti yang diharapkan. IPA menjadi mata pelajaran yang dianggap sulit dikalangan siswa sekolah dasar. Disebabkan oleh lemahnya pelaksanaan proses pembelajaran yang diterapkan para guru di sekolah. Guru belum optimal dalam memvariasikan pertanyaan yang menyebabkan kegiatan pembelajaran menjadi kurang interaktif. Permasalahan tersebut tentunya berdampak pada hasil belajar IPA siswa yang kurang optimal. Seperti yang terjadi di sekolah dasar Gugus VII Kecamatan Sawan. Pada studi dokumentasi yang dilaksanakan, nilai UAS (Ulangan Akhir Semester) mata pelajaran IPA siswa kelas V semester I diketahui bahwa jumlah siswa yang mencapai KKM sebanyak 33 siswa dan yang belum mencapai KKM sebanyak 45 siswa dari total 78 siswa. Jika dilihat dari rata-rata persentase pencapaian KKM, sebanyak 63,57\% belum mencapai KKM dan hanya 36,43\% yang mencapai KKM. Jadi dari data tersebut dapat disimpulkan bahwa hasil belajar IPA siswa masih rendah.

Berbagai faktor dapat mempengaruhi rendahnya hasil belajar siswa di SD Gugus VII Kecamatan Sawan. Terdapat beberapa permasalahan dalam pembelajaran yang didapat dari hasil observasi dan wawancara dengan guru kelas V SD pada tanggal 8 sampai dengan 10 Januari 2018. Pertama, guru masih menerapkan pembelajaran konvensional. Pembelajaran konvensional yang dimaksud adalah pembelajaran di kelas yang masih berpusat pada guru (teacher centered). Guru lebih mendominasi pembelajaran dan siswa cenderung pasif. Siswa hanya mendengarkan dan mencatat, sesuai perintah guru tanpa berupaya menemukan sendiri konsep-konsep yang telah dipelajari. Kedua, guru kesulitan mengembangkan rencana pembelajaran. Guru tidak banyak mengenal model-model pembelajaran yang inovatif menjadi salah satu faktor sulitnya mengembangkan rencana pembelajaran, sehingga ketika proses pembelajaran berlangsung guru hanya mengandalkan metode ceramah. Ketiga, pembelajaran di kelas yang jarang menggunakan media pembelajaran yang mampu membuat siswa mencerna informasi 
dengan baik dan lebih menarik perhatian siswa agar mampu memahami konsep yang disampaikan oleh guru. Hal ini juga disebabkan oleh kurangnya fasilitas yang ada di sekolah dan keterbatasan waktu yang dimiliki guru untuk membuat suatu media pembelajaran.

Rendahnya hasil belajar IPA tersebut, perlu adanya upaya untuk memperbaiki proses pembelajaran IPA agar pembelajaran yang dilaksanakan dapat memberikan hasil yang optimal, sehingga mampu meningkatkan hasil belajar pada siswa. Perlu diterapkan strategi pembelajaran yang efektif dan menyenangkan agar dapat memotivasi siswa ikut aktif dalam proses pembelajaran, sehingga siswa tidak takut lagi dalam mengikuti pembelajaran IPA di sekolah. Perlu diadakan pembaruan dalam sistem pembelajaran. Sistem pembelajaran hendaknya dirancang sedemikian rupa sehingga proses pembelajaran dapat berlangsung dengan kondusif agar terjadi peningkatan hasil belajar siswa khususnya pada mata pelajaran IPA. Hasil belajar IPA merupakan salah satu indikator untuk dapat meningkatkan keberhasilan belajar, sehingga perlu adanya inovasi dalam melaksanakan pembelajaran IPA. Salah satu inovasi yang dapat dilakukan dengan menggunakan model pembelajaran yang menyenangkan sehingga meningkatkan keinginan siswa dalam mengikuti proses pembelajaran yang diberikan. Salah satu cara yang bisa ditempuh adalah dengan menciptakan pembelajaran yang berpusat pada siswa (student centered). Dapat dilakukan dengan menerapkan model pembelajaran yang sesuai dengan karakteristik siswa dan permasalahan yang dialami.

Model pembelajaran kolaboratif melibatkan sekelompok siswa yang bekerja sama melalui interaksi yang dilakukan untuk menyelesaikan suatu masalah yang diberikan oleh guru, mengerjakan tugas, dan menghasilkan suatu produk. Meskipun pembelajaran kolaboratif membagi siswa menjadi beberapa kelompok, namun ketika proses pembelajaran berlangsung tetap didukung oleh kemampuan yang dimiliki oleh masing-masing siswa. Nantinya setiap siswa akan menyumbangkan informasi, pengalaman, ide, sikap, dan keterampilan yang dimilikinya untuk meningkatkan pemahaman seluruh anggota kelompoknya secara bersama-sama. Melalui interaksi dan kerjasama pada setiap kelompok dalam memecahkan suatu masalah, akan terciptanya suatu pembelajaran yang melibatkan siswa secara aktif. Menurut Marhamah, dkk. (2017) hal yang paling penting dalam pembelajaran kolaboratif adalah bagaimana membuat siswa fokus yang dapat diwujudkan oleh adanya 'materi lompatan' (jumping task) di setiap pelaksanaan pembelajaran kolaboratif. Sebelum diberikan jumping task siswa akan diberikan sharing task terlebih dahulu sebagai tuntunan untuk membangun pengetahuan sendiri sesuai dengan materi yang diberikan, sehingga model pembelajaran kolaboratif dapat menjadi model pembelajaran inovatif yang menjadikan siswa sebagai pusat pembelajaran (student centered) dengan menekankan adanya suatu interaksi sosial, kerja sama, dan pertukaran informasi pada kelompok-kelompok kecil yang lebih mengutamakan pada keberhasilan proses yang ditunjukkan dengan adanya materi lompatan.

Keefektifan model pembelajaran kolaboratif pernah diterapkan dalam penelitian yang dilakukan oleh Susanto (2013) dan Marhamah, dkk. (2017) menyatakan bahwa penggunaan model pembelajaran Collaborative Learning dapat meningkatkan hasil belajar pada siswa dilihat dari rata-rata hasil belajar siswa. Penelitian yang dilakukan oleh Susanto menyatakan bahwa rata-rata skor hasil belajar yang dibelajarkan dengan menggunakan model pembelajaran kolaboratif berkategori sangat tinggi dan ratarata skor hasil belajar pada kelompok siswa yang dibelajarkan menggunakan metode ceramah berkategori rendah. Selain itu penelitian yang dilakukan oleh Marhamah, dkk. (2017) menyatakan bahwa model pembelajaran kolaboratif berpengaruh terhadap hasil belajar IPA. Berdasarkan hasil penelitian tersebut dapat dilihat bahwa hasil belajar siswa yang dibelajarkan menggunakan model kolaboratif lebih baik dari pada siswa yang dibelajarkan dengan pembelajaran konvensional.

Pembelajaran kolaboratif dapat juga disebut sebagai collaborative learning. Model pembelajaran kolaboratif merupakan salah satu model pembelajaran efektif. Menurut Doin, dkk (dalam Margowati, 2009) kolaboratif berasal dari kata collaboration dalam bahasa Inggris yang artinya suatu proses dimana dua orang atau lebih merencanakan, mengimplementasikan, dan mengevaluasi kegiatan bersama. Santoso (2013) menyatakan bahwa pembelajaran kolaboratif adalah suatu situasi dimana dua orang atau lebih belajar atau mencoba belajar sesuatu secara bersama-sama yang berbeda halnya dengan belajar sendiri. Maksudnya, orang-orang yang terlibat dalam pembelajaran kolaboratif memanfaatkan sumber daya dan keterampilan yang dimiliki orang lain dalam kelompoknya, misalnya meminta informasi, saling menilai gagasan, dan memantau pekerjaan satu sama lain. Maka dapat dikatakan model pembelajaran kolaboratif ini lebih menekankan pada kerja sama, adanya interaksi sosial didalam proses pembelajaran, dan pertukaran informasi didalam kelompok yang lebih memfokuskan pada keterampilan proses yang berpusat pada siswa.

Menurut Marhamah dkk (2017) hal yang paling penting dalam pembelajaran kolaboratif adalah bagaimana membuat siswa fokus yang dapat diwujudkan oleh adanya 'materi lompatan' (jumping task) disetiap pelaksanaan pembelajaran kolaboratif. Sebelum diberikan materi lompatan yang berupa soal-soal maupun LKS siswa terlebih dahulu diberikan sharing task. Dalam mengerjakan sharing task siswa 
berdiskusi dengan teman sekolompoknya ataupun kelompok lain yang dimediatori oleh guru. Pada saat sharing task siswa akan bertukar informasi, bersosialisasi, dan bekerja sama untuk memecahkan masalah yang diberikan, namun dalam penyusunan laporan siswa tetap mengerjakan secara individu. Sharing task bisa diberikan lebih dari sekali tergantung kebutuhan dari siswa. Sharing task bisa dikatakan sebagai jembatan menuju ke jumping task (materi lompatan) sehingga pada materi lompatan siswa dengan mudah dapat menyelesaikan/memecahkan permasalahan yang ada.

Keefektifan model pembelajaran kolaboratif pernah diterapkan dalam penelitian yang dilakukan oleh Susanto (2013) dan Marhamah dkk (2017) menyatakan bahwa penggunaan model pembelajaran Collaborative Learning dapat meningkatkan hasil belajar pada siswa dilihat dari rata-rata hasil belajar siswa. Penelitian yang dilakukan oleh Susanto menyatakan bahwa rata-rata skor hasil belajar yang dibelajarkan dengan menggunakan model pembelajaran kolaboratif berkategori sangat tinggi dan ratarata skor hasil belajar pada kelompok siswa yang dibelajarkan menggunakan metode ceramah. Selain itu penelitian yang dilakukan oleh Marhamah dkk (2017) menyatakan bahwa model pembelajaran kolaboratif berpengaruh terhadap hasil belajar IPA. Berdasarkan hasil penelitian tersebut dapat dilihat bahwa hasil belajar siswa yang dibelajarkan menggunakan model kolaboratif lebih baik dari pada siswa yang dibelajarkan dengan pembelajaran konvensional.

Selain penggunaan model pembelajaran yang tepat, alat bantu juga dapat digunakan untuk mendukung agar tujuan pembelajaran dapat tercapai secara maksimal. Alat bantu yang digunakan dalam penelitian ini yaitu berupa pembuatan peta pikiran oleh peserta didik. Media berupa peta pikiran sangat tepat digunakan dalam memberikan materi pembelajaran kepada siswa khususnya pada mata pelajaran IPA. Adanya pembuatan peta pikiran akan membantu peserta didik dalam proses mencatat, sehingga peserta didik akan lebih mudah dalam memahami materi yang disampaikan oleh guru dalam bentuk catatan kreatif seperti peta rute yang mempunyai banyak cabang. Membuat peta pikiran merupakan salah satu cara untuk mengasimilasi konsep-konsep yang telah dipelajari oleh siswa (Wardani, 2015), sehingga pembelajaran yang telah diperoleh menjadi lebih terstruktur dan terorganisr dengan baik. Pembuatan peta pikiran usahakan menggunakan gambar, simbol atau kode.

Berdasarkan uraian tersebut, dilakukan penelitian yang bertujuan mengetahui (1) perbedaan yang signifikan hasil belajar IPA antara siswa yang dibelajarkan dengan model pembelajaran kolaboratif berbantuan peta pikiran dan siswa yang mengikuti pembelajaran konvensional pada siswa kelas V SD di Gugus VII Kecamatan Sawan Tahun Pelajaran 2017/2018

\section{Metode}

Jenis penelitian ini adalah eksperimen semu (quasi experiment), disebut demikian karena tidak semua variabel yang muncul dapat dikontrol secara ketat. Desain yang digunakan dalam penelitian ini adalah non-equivalen post-test only control group design karena tidak mungkin mengubah kelas-kelas atau struktur yang sudah ada. Populasi dalam penelitian ini adalah seluruh siswa kelas V SD di Gugus VII Kecamatan Sawan Tahun Pelajaran 2017/2018 yang berjumlah 70 siswa. Pemilihan sampel menggunakan teknik random sampling atau pengundian tanpa pengembalian dan yang diundi kelas bukan siswa dalam kelas sebanyak dua kali, yaitu menentukan sampel penelitian serta menentukan kelompok kelas eksperimen dan kelompok kelas kontrol. Sekolah sampel adalah SD Negeri 3 Sinabun yang berjumlah 26 siswa terpilih menjadi kelompok eksperimen dan SD Negeri 3 Suwug yang berjumlah 18 siswa terpilih menjadi kelompok kontrol.

Penelitian ini melibatkan dua variabel, yaitu variabel bebas, variabel terikat, dan variabel kontrol. Bertindak sebagai variabel bebas adalah model pembelajaran kolaboratif berbantuan peta pikiran dan hasil belajar bertindak sebagai variabel terikat. Model pembelajaran kolaboratif berbantuan peta pikiran diterapkan pada kelompok eksperimen dan kelompok kontrol menerapkan pembelajaran kovensional. Pembelajaran konvensional artinya pembelajaran yang sudah biasa dlaksanakan di kelas tersebut meliputi, metode ceramah, penugasan dan hanya mencatat apa yang disampaikan oleh guru di kelas dan tidak menerapkan model pembelajaran kolaboratif berbantuan peta pikiran. Proses pembelajaran dilaksanakan sebanyak delapan kali, yaitu tujuh kali pembelajaran dan satu kali post-test pada pertemuan kedelapan. Data mengenai hasil belajar IPA diperoleh melalui metode tes. Tes hasil belajar IPA siswa berupa tes objektif (pilihan ganda) dengan jumlah soal 30 soal. Sebelum instrument digunakan dalam penelitian, perlu dilakukan uji coba terhadap instrumen hasil belajar IPA untuk mengetahui apakah instrument layak digunakan atau tidak. Uji coba instrumen hasil belajar IPA dilakukan pada siswa kelas VI di Gugus VII Kecamatan Sawan, yaitu siswa SD Negeri 2 Sinabun yang berjumlah 42 siswa, dan SD Negeri 2 Suwug 12 siswa.

Data dianalisis menggunakan statistik deskriptif dan statistik inferensial. Statistik deskriptif digunakan untuk mendeskripsikan data yang meliputi mean, median, modus, varians, dan standar deviasi. 
Statistik inferensial/uji prasyarat digunakan untuk mengetahui data hasil belajar berdistribusi (1) uji normalitas sebaran data dilakukan untuk mengetahui data hasil belajar IPA berdistribusi normal atau tidak, (2) uji homogenitas varians dilakukan untuk mengetahui data hasil belajar IPA dari dua kelompok memiliki tingkat kemampuan yang sama/setara atau tidak.

\section{Hasil dan Pembahasan}

Rangkuman deskripsi data hasil belajar IPA pada kelompok eksperimen dan kontrol dapat dilihat pada Tabel 1.

Tabel 1. Rangkuman Deskripsi Data Hasil Belajar IPA

\begin{tabular}{ccc}
\hline \multirow{2}{*}{ Statistik Deskriptif } & \multicolumn{2}{c}{ Hasil Belajar IPA } \\
& Kelompok Eksperimen & Kelompok Kontrol \\
\hline Mean & 24,81 & 17,00 \\
Median & 24,83 & 15,00 \\
Modus & 24,90 & 14,79 \\
Varians & 17,05 & 16,88 \\
Standar Deviasi & 4,13 & 4,10 \\
Skor Maksimun & 30 & 26 \\
Skor Minimum & 15 & 10 \\
Rentangan & 16 & 17 \\
\hline
\end{tabular}

Berdasarkan hasil analisis statistik deskriptif pada Tabel 1, Skor hasil belajar IPA kelompok eksperimen, dapat dideskripsikan yaitu: mean $(M)=24,81$; median $(\mathrm{Md})=24,83$; modus $(\mathrm{Mo})=24,90$; varians (s2) =17,05; dan standar deviasi (s) = 4,13. Dapat diketahui bahwa modus lebih besar dari median dan median lebih besar dari mean (Mo $>$ Md $>$ M). Sementara itu, skor hasil belajar IPA kelompok kontrol, yaitu: mean $(M)=17,00$; median $(M d)=15,00$; modus $(M o)=14,79$; varians $(\mathrm{s} 2)=16,88$; dan standar deviasi $(s)=4,10$. Dapat diketahui bahwa modus lebih kecil dari median dan median lebih kecil dari mean $(\mathrm{Mo}<\mathrm{Md}<\mathrm{M})$. Pada kelompok eksperimen sebagian skor siswa cenderung tinggi, dapat dilihat pada gambar hasil belajar IPA kelompok eksperimen yang disajikan dalam bentuk kurva polygon pada Gambar 1.

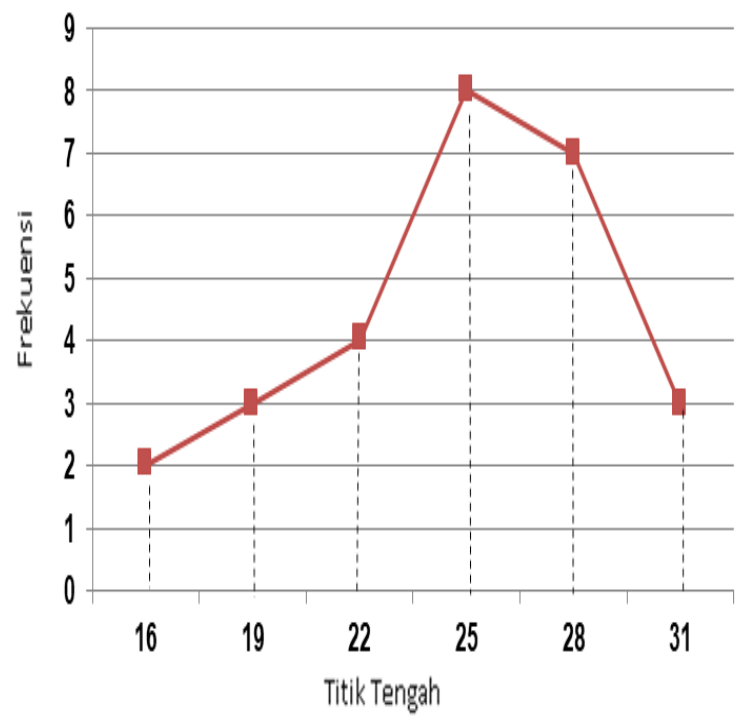

Gambar 1. Kurva Poligon Data Hasil Belajar Kelompok Eksperimen

Pada kelompok kontrol sebagian skor hasil belajar IPA siswa cenderung rendah, dapat dilihat pada gambar hasil belajar IPA kelompok eksperimen yang disajikan dalam bentuk kurva poligon pada Gambar 2. 


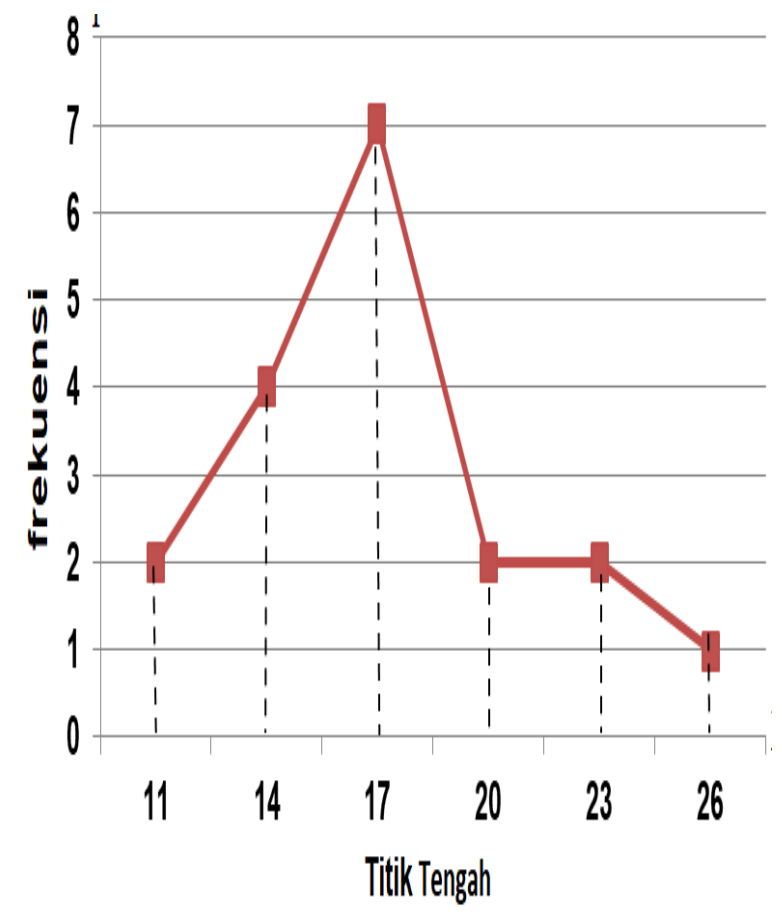

Gambar 2. Kurva Poligon Data Hasil Belajar Kelompok Kontrol

Hasil uji prasyarat menunjukkan data berdistribusi normal, dan memiliki variansi homogen. Merujuk pada hasil uji prasyarat tersebut, uji hipotesis pertama dan hipotesis kedua dapat dilakukan. Hasil uji hipotesis menggunakan uji t sampel independent dengan rumus polled varians menunjukkan nilai $t_{\text {hitung }}=6,06$ sedangkan $t_{\text {tabel }}$ dengan $d b=n_{1}+n_{2}-2=(26+18-2)=42$ untuk taraf signifikansi $5 \%=$ 2,021. Ini berarti, nilai $t_{\text {hitung }}$ lebih besar dari pada $t_{\text {tabel }}\left(t_{\text {hitung }}=5,96>t_{\text {tabel }}=2,021\right)$, sehingga $H_{0}$ ditolak dan $\mathrm{H}_{1}$ diterma. Jadi terdapat perbedaan yang signifikan hasil belajar IPA siswa yang dibelajarkan dengan model pembelajaran kolaboratif berbantuan peta pikiran dan siswa yang mengikuti pembelajaran konvensional.

Pengujian hipotesis yang telah dilakukan berhasil membuktikan bahwa terdapat perbedaan yang signifikan hasil belajar IPA siswa yang dibelajarkan dengan model pembelajaran kolaboratif berbantuan peta pikiran dan siswa yang mengikuti pembelajaran konvensional pada siswa kelas V SD di Gugus VII Kecamatan Sawan Tahun Pelajaran 2017/2018. Perbedaan hasil belajar IPA tersebut membuktikan bahwa hasil belajar IPA siswa yang dibelajarkan dengan model pembelajaran kolaboratif berbantuan peta pikiran pada kelompok eksperimen lebih baik dibandingkan hasil belajar IPA siswa yang mengikuti pembelajaran konvensional pada kelompok kontrol. Terdapat beberapa hal yang menyebabkan hasil belajar IPA kelompok siswa yang dibelajarkan dengan model pembelajaran kolaboratif berbantuan peta pikiran lebih baik dibandingkan dengan hasil belajar IPA kelompok siswa yang mengikuti pembelajaran konvensional sebagai berikut.

Pertama, selama proses pembelajaran berlangsung siswa dituntun mencari tahu sendiri jawaban atas permasalahan yang diberikan melalui berbagai kegiatan percobaan dalam kelompok kecil. Penelitian yang dilakukan oleh Marhamah (2017) menunjukkan terdapat pengaruh hasil belajar siswa setelah menggunakan model pembelajaran kolaboratif berbasis lesson study learning community dalam belajar IPA. Sharing task dan jumping task penting diberikan dalam pembelajaran kolaboratif untuk membuat siswa fokus dalam mengikuti pembelajaran, sehingga hasil belajar siswa dapat meningkat. Kegiatan percobaan yang dilakukan siswa dilanjutkan dengan pemberian sharing task yang berada pada level buku pelajaran dan jumping task yang berada pada level di luar buku pelajaran. Pembelajaran menjadi tidak monoton dan menyenangkan karena siswa diberikan tantangan secara bertahap untuk menemukan konsep dan mengembangkan konsep pada materi yang diberikan. Selama mengerjakan materi sharing atau jumping, siswa tetap melakukan kolaborasi atau bergantung secara positif dengan anggota kelompok kecil dan siswa lain namun hasil akhir tetap dipertanggungjawabkan oleh setiap siswa. Konsep tersebut membuat siswa berani mempertanggungjawabkan apa yang dikerjakan dan tidak hanya mengandalkan anggota kelompok yang mampu. Tidak jarang terjadi perbedaan pendapat dalam satu kelompok atau pada 
kelompok yang berbeda. Pada situasi tersebut guru berperan sebagai mediator dan fasilitaor untuk mewadahi pendapat siswa dan bersama siswa membuat simpulan.

Kedua, posisi tempat duduk seperti huruf U membuat suasana kelas menjadi lebih kondusif, siswa merasa senang karena tidak ada yang duduk paling belakang atau paling depan. Seluruh aktivitas siswa dapat terlihat jelas, dan setiap siswa bisa saling memerhatikan, sehingga siswa yang bermain saat pemebalajaran berlangsung dapat melihat teman yang serius mengikuti pembelajaran dan siswa tersebut merasa tertantang juga untuk serius dalam mengikuti pembelajaran maupun penjelasan guru. Posisi tempat duduk seperti huruf U juga memudahkan guru melakukan bimbingan kepada setiap siswa. Efesiensi waktu juga menjadi kelebihan model pembelajaran kolaboratif karena saat pembentukkan kelompok siswa hanya perlu berbalik badan dengan suasana kelas tetap kondusif. Kelompok dengan anggota 4 orang lebih efektif karena seluruh anggota kelompok akan bekerja dan tidak ada yang dikucilkan. Heterogen dari segi jenis kelamin dan kemampuan membuat kolaborasi yang terjadi semakin baik karena siswa yang memiliki kemampuan lebih tinggi bersemangat memberikan informasi kepada siswa yang memiliki kemampuan lebih rendah, sehingga keduanya mendapatkan manfaat yang sama. Jadi model pembelajaran kolaboratif yang menerapkan sistem kelompok kecil sudah mampu berjalan dengan efektif.

Ketiga, konsep-konsep yang telah diperoleh siswa melalui pembelajaran kolaboratif diorganisirkan dengan membuat peta pikiran. Siswa menjadi lebih termotivasi dalam pembelajaran karena adanya pembuatan peta pikiran pada akhir pembelajaran. Hal ini didukung dengan pendapat Buzan (2007) bahwa peta pikiran lebih menarik dan merangsang daripada teknik mencatat tradisional. Dalam pembelajaran kolaboratif, peta pikiran dibuat pada akhir pembelajaran setalah siswa memperoleh informasi dan kemudian memvisualisasikan dalam bentuk peta pikiran yang menarik. Kegiatan ini membuat pengetahuan yang telah diperoleh melalui pembelajaran kolaboratif menjadi lebih terstruktur dan terorganisir sehingga daya ingat siswa terhadap materi pelajaran cenderung lebih lama. Hal ini sesuai dengan pendapat Wardani (2015) yang menyatakan bahwa membuat peta pikiran merupakan salah satu cara untuk mengasimilasi konsep-konsep yang telah dipelajari oleh siswa. Berdasarkan paparan tersebut, model pembelajaran kolaboratif memberikan pengaruh terhadap proses pembelajaran yang berlangsung, sehingga terjadi peningkatan hasil belajar IPA khususnya pada ranah kognitif.

Berbeda halnya dengan pembelajaran yang dilaksanakan di kelas kontrol yang mengikuti pembelajaran konvensional, siswa cenderumg pasif dalam menggali pengetahuannya. Pembelajaran yang dilaksanakan masih berpusat pada guru. Guru mendominasi proses pembelajaran dengan menjelaskan materi pembelajaran, melakukan tanya jawab kepada siswa kemudian memberikan tugas kepada siswa untuk diberikan nilai. Hal ini membuat siswa hanya mendengarkan dan mencatat tentang apa yang disampaikan oleh guru tanpa berupaya untuk menemukan sendiri konsep-konsep yang dipelajari.

Hasil penelitian ini sejalan dengan hasil penelitian yang dilakukan oleh Ika Dewi Primadiati dan D.Djukri (2014) pada siswa kelas IV SD Catur Tunggal 3 menyatakan bahwa terdapat perbedaan hasil belajar siswa yang dibelajarkan dengan menggunakan model pembelajaran collaborative learning dengan perbedaan rata-rata sebesar 4,51.

\section{Simpulan dan Saran}

Berdasarkan hasil penelitian dan pembahasan, dapat disimpulkan pada penelitian terdapat perbedaan yang signifikan hasil belajar IPA antara siswa yang dibelajarkan dengan model pembelajaran kolaboratif berbantuan peta pikiran dan siswa yang mengikuti pembelajaran konvensional pada siswa kelas V SD di Gugus VII Kecamatan Sawan Tahun Pelajaran 2017/2018. Simpulan tersebut diperoleh dari hasil uji hipotesis menggunakan uji-t sampel independent. Dengan menggunakan rumus polled varians diperoleh rata-rata skor hasil belajar IPA siswa yang dibelajarkan dengan model pembelajaran kolaboratif berbantuan peta pikiran lebih besar dibandingkan rata-rata skor hasil belajar IPA siswa yang mengikuti pembelajaran konvensional $(24,81>17,00)$. hasil pengujian hipotesis menunjukkan nilai $t_{\text {hitung }}$ yaitu, 5,96 lebih besar dari $t_{\text {tabel }}$ yaitu 2,021 pada taraf signifikansi 5\% yang artinya terdapat perbedaan yang signifikan hasil belajar IPA antara kelompok siswa yang dibelajarkan dengan model pembelajaran kolaboratif berbantuan peta pikiran dan kelompok sisw yang mengikuti pembelajaran konvensional pada siswa kela V SD di Gugus VII Kecamatan Sawan Tahun Pelajaran 2017/2018.

Saran yang dapat disampaikan berdasarkan penelitian yang telah dilakukan, sebagai berikut. (1) Siswa dalam mengikuti proses pembelajaran diharapkan lebih aktif melakukan interaksi dengan teman di kelas baik dalam kelompok kecil atau klasikal. Siswa yang sudah menguasi materi diharapkan membagi informasi yang dimiliki dengan siswa lain dan siswa yang belum menguasai materi diharapkan bertanya pada siswa lain yang dianggap mampu, sehingga kolaborasi dalam bentuk hubungan saling belajar dapat terjadi. Informasi tidak hanya bersumber dari guru tetapi juga dari siswa. Siswa juga diharapkan belajar 
saling mendengarkan, sehingga lebih banyak informasi yang dapat dipahami. (2) Guru diharapkan lebih berinovasi dalam menggunakan model pembelajaran agar dapat mencapai tujuan pembelajaran yang sesuai dengan karakteristik mata pelajaran tersebut, khususnya pada mata pelajaran IPA. Salah satunya adalah dengan menerapkan model pembelajaran kolaboratif untuk meningkatkan hasil belajar IPA siswa, guru harus memantau, membimbing, memfasilitasi, dan memotivasi siswa dalam proses pembelajaran. Hal ini diperlukan agar guru dapat membantu siswa menjadi pribadi yang lebih baik dalam perkembangan mental dan sosial siswa. (3) Kepala sekolah hendaknya menghimbau guru-guru untuk melaksanakan pembelajaran menggunakan model-model pembelajaran inovatif, salah satunya adalah menerapkan model kolaboratif untuk meningkatkan hasil belajar IPA siswa. (4) Peneliti lain yang berminat mengadakan penelitian lebih lanjut tentang model pembelajaran kolaboratif diharapkan menambah variabel-variabel yang akan diteliti baik variabel terikat, variabel kontrol ataupun variabel moderator dan dapat melaksanakan penelitian untuk mata pelajaran selain IPA.

\section{Daftar Rujukan}

Agung, Anak Agung Gede. 2014. Buku Ajar Metodologi Penelitian Pendidikan. Universitas Pendidikan Ganesha.

Armiati, Sari, dkk. 2007. “Collaborative Learning Framework”. SNATI, ISSN: 1907-5002.

Barkley, E., dkk. 2014. Teknik-Teknik Pembelajaran Kolaboratif. Terjemahan Narulita Yusron. Collaborative Learning Techniques. 2005. Bandung: Nusamedia.

Budi Wicaksana,Rony. 2012. Penerapan Pembelajaran IPA Dengan Strategi Mind Mapping (Peta Pikiran) Terhadap Hasil Belajar Siswa Pada Materi Ekosistem Kelas VII SMP Negeri 3 Madiun. Jurnal Pendidikan Sains, Vol.1, No.1.

Candiasa, M. 2011. Pengujian Instrumen Penelitian Disertai Aplikasi ITEMAN dan BIGSTEPS. Singaraja: Undiksha Press.

Logina Linto, Rendya dkk. 2012. Kemampuan Koneksi Matematis Dan Metode Pembelajaran Quantum Teaching Dengan Peta Pikiran. Jurnal Pendidikan Matematika, Vol. 1, No.1.

Peraturan Menteri Pendidikan Nasional Republik Indonesia Nomor 23 Tahun 2006 tentang Standar Kompetensi Lulusan untuk Satuan $\quad$ Pendidikan Dasar dan Menengah. 2006. Jakarta: Kementerian Pendidikan Nasional.

Purwasari,Yosi. 2013. Meningkatkan Hasil Belajar Ipa Tentang Perubahan Kenampakkan Permukaan Bumi Dan Benda Langit Melalui Peta Pikiran Pada Anak Kesulitan Belajar Kelas IV SD 13 Balai Balai Kota Padang Panjang. Jurnal Ilmiah Pendidikan Khusus, Vol. 1, No.1.

Samatowa, U. 2010. Pembelajaran IPA di Sekolah Dasar. Tanggerang Selatan: Universitas Terbuka.

Santoso, S. 2013. "Pengaruh Model Pembelajaran Kolaboratif dan Motivasi Belajar Terhadap Peningkatan Hasil Belajar Fisika Kelas X SMA Negeri 1 Purwantoro Wonogiri, Jawa Tengah". Berkala Fisika Indonesia. Volume 5 Nomor 1 (hlm. 15-19).

Situmorang, Rappel. 2013. Pengaruh Metode Peta Pikiran Terhadap Hasil Belajar Siswa Pada Materi Suhu Dan Kalor Di SMA Negeri 2 Tebing Tinggi. Jurnal Penelitian Bidang Pendidikan, Vol. 19, No.1.

Sugiyono. 2011. Statistika untuk Penelitian. Bandung: Alafabeta.

Susanto, Ahmad. 2014. Teori Belajar \& Pembelajaran di Sekolah Dasar. Jakarta: Kencana Prenadamedia Group.

Margowati, Danik. Penerapan Model Pembelajaran Kolaboratif Disertai Strategi Quantum Learning dalam Meningkatkan Hasil Belajar Biologi. S Skripsi (tidak diterbitkan). Universitas Sebelas Maret. 
Marhamah, dkk. 2017. "Pengaruh Model Pembelajaran Kolaboratif Berbasis Lesson Study Learning Community (LSLC)”. Jurnal Ilmiah Mahasiswa (JIM) Pendidikan Fisika, Volume 2, Nomor 3 (hlm. 277-282).

Shoimin, A. 2014. 68 Model $\quad$ Pembelajaran Inovatif dalam $\quad$ Kurikulum 2013. Yogyakarta: Ar- Ruzz Media.

Syahrir dan Elma Heliati. 2017. Analisis Mind Map Siswa Kelas VII C Smpn 6 Kopang. Jurnal Ilmiah Mandala Education (JIME), Vol. 3, No.1

Wahida, M. 2014. "Pengaruh Model Pembelajaran Inkuiri Terbimbing dan Motivasi Berprestasi Terhadap Hasil Belajar IPA Siswa Kelas V SD Di Kelurahan Kaliuntu Tahun Pelajaran 2015/2016". Mimbar PGSD Unniversitas Pendidikan Ganesha. Volume 4, Nomor 1 (hlm. 1-11). 